\title{
EMILIN1 Gene
}

National Cancer Institute

\section{Source}

National Cancer Institute. EMILIN1 Gene. NCI Thesaurus. Code C24362.

This gene may play a role in cellular adhesion and elastin deposition; however, a specific function has not been identified. 